\title{
Depurination of colibactin-derived interstrand cross-links
}

\author{
Mengzhao Xue, ${ }^{1}$ Kevin Wernke, ${ }^{1}$ and Seth B. Herzon ${ }^{*}, 1,2$ \\ ${ }^{1}$ Department of Chemistry, Yale University, New Haven, Connecticut 06520, United States. \\ ${ }^{2}$ Department of Pharmacology, Yale School of Medicine, New Haven, Connecticut 06520, \\ United States
}

E-mail: seth.herzon@yale.edu

\section{Biochemistry}

Supporting Information

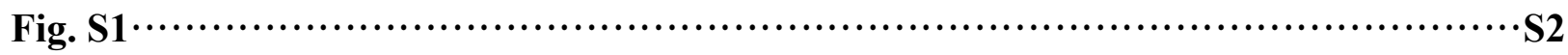

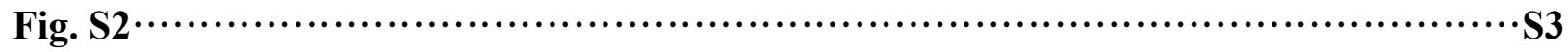

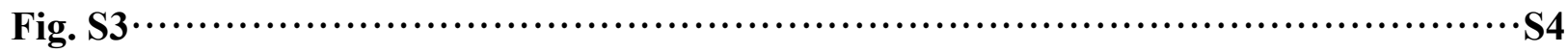

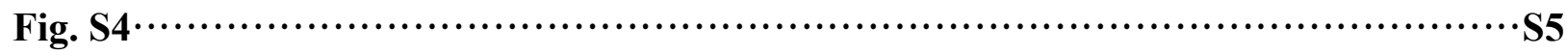

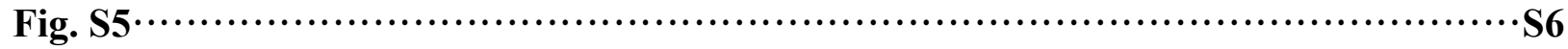

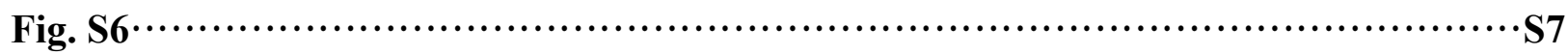

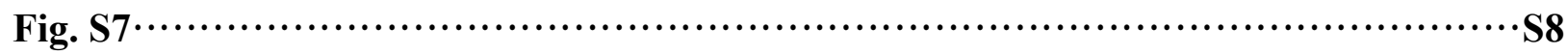

Fig. S8

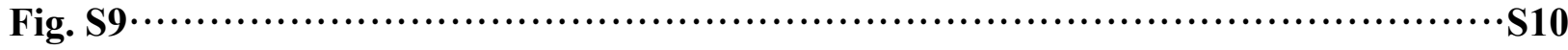

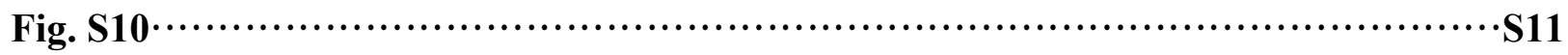

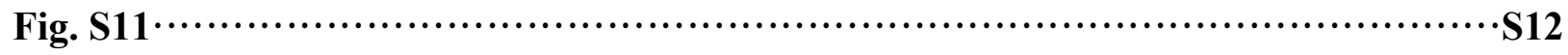

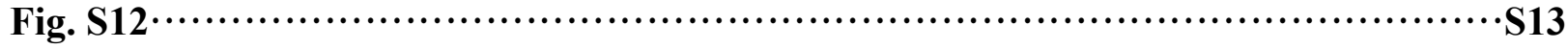

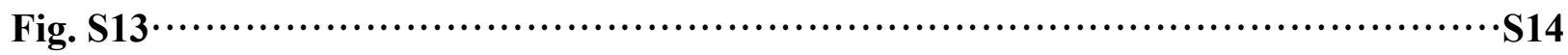

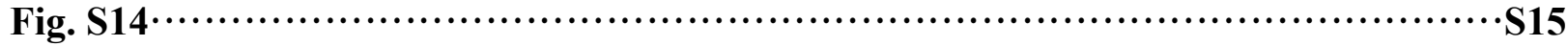

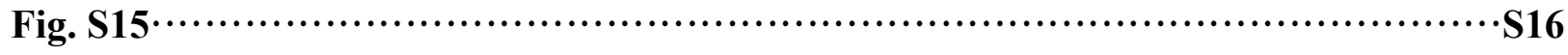

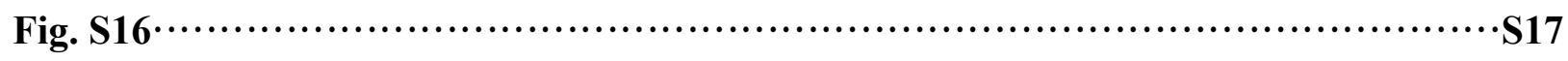

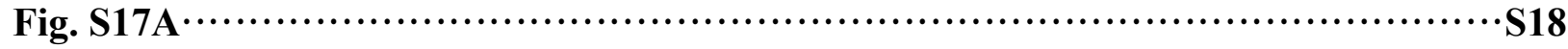

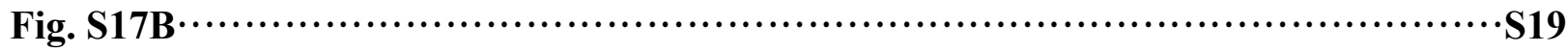



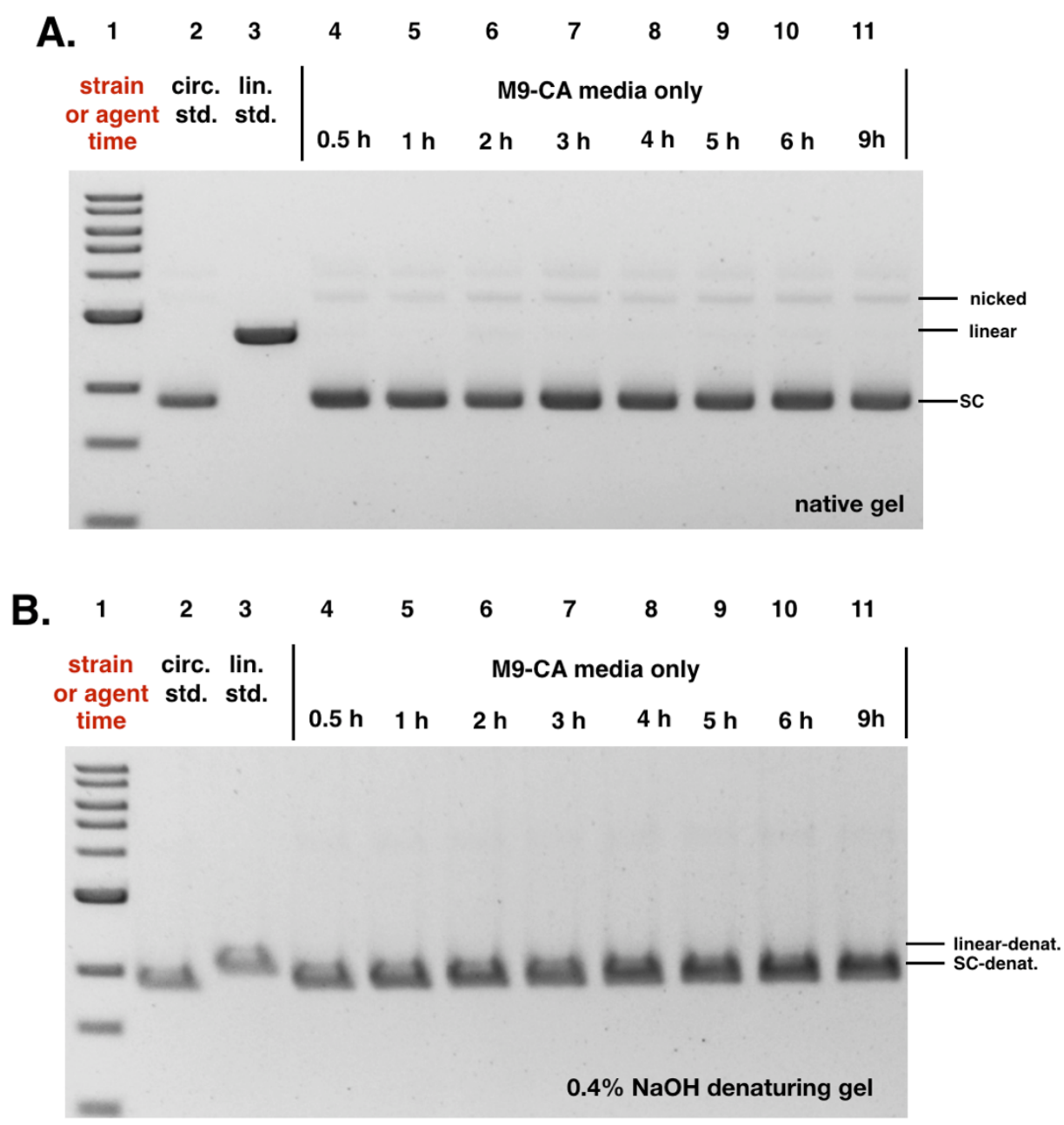

Fig. S1. DNA plasmid cleavage assay employing circular pUC19 DNA and M9-cas amino acid media (M9-CA media) only. A. Native gel; B. 0.4\% NaOH denaturing gel. DNA ladder (Lane \#1); circular pUC19 DNA standard (Lane \#2); linearized pUC19 DNA standard (Lane \# 3); M9-CA media $0.5 \mathrm{~h}$ (Lane \#4), $1 \mathrm{~h}$ (Lane \#5), $2 \mathrm{~h}$ (Lane \#6), $3 \mathrm{~h}$ (Lane \#7) $4 \mathrm{~h}$ (Lane \#8), $5 \mathrm{~h}$ (Lane \#9), $6 \mathrm{~h}$ (Lane \#10), and $9 \mathrm{~h}$ (Lane \#11). Conditions (Lane \#4-\#11): circular pUC19 DNA ( $7.7 \mu \mathrm{M}$ in base pairs), M9-CA media, $37^{\circ} \mathrm{C}$, reaction proceed for $0.5 \mathrm{~h}, 1 \mathrm{~h}, 2 \mathrm{~h}, 3 \mathrm{~h}, 4 \mathrm{~h}, 5 \mathrm{~h}, 6 \mathrm{~h}$, and $9 \mathrm{~h}$. The DNA was isolated, purified, and analyzed either (Fig. S1A) by native agarose gel electrophoresis, or (Fig. S1B) by $0.4 \% \mathrm{NaOH}$ denaturing agarose gel electrophoresis $(90 \mathrm{~V}, 2 \mathrm{~h}$ ). SC-denat. = supercoiled DNA in denaturing form, linear-denat. = linearized DNA in denaturing form. 

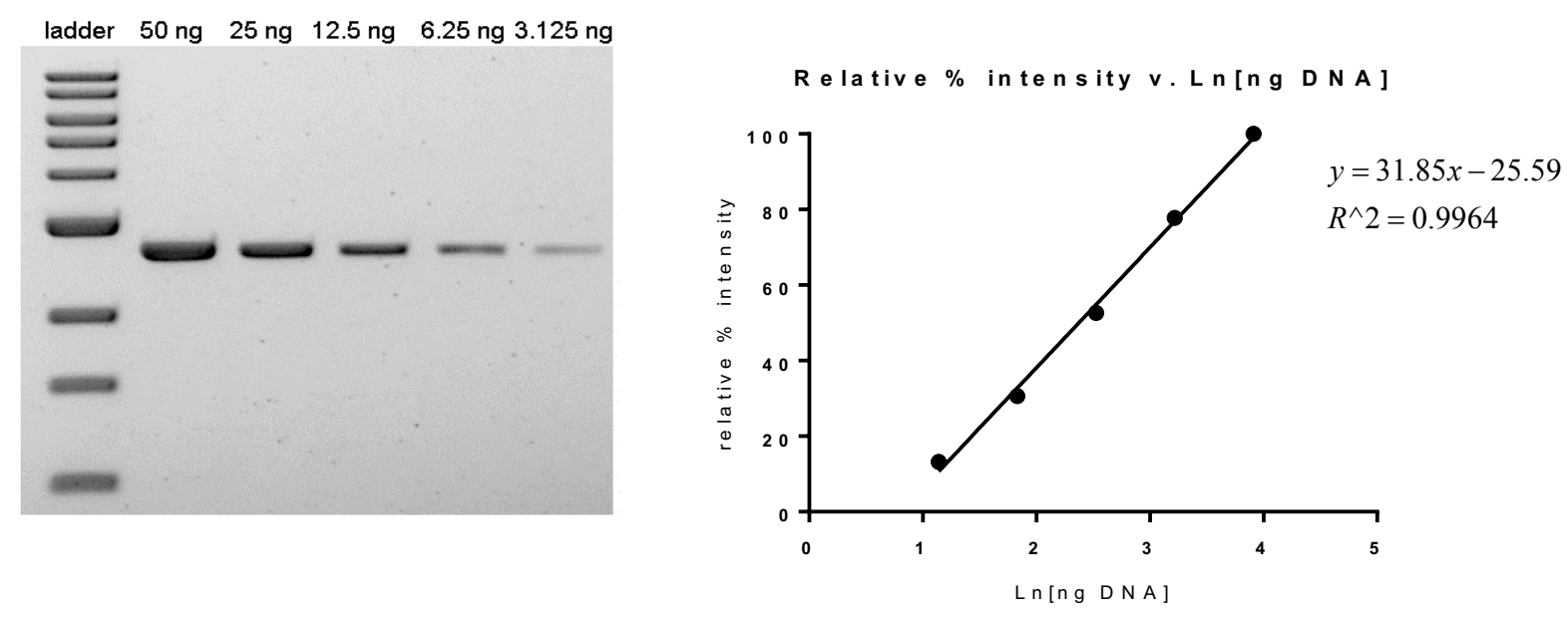

Fig. S2. Calibration curve correlating the intensity of the gel band with the amount of DNA present. DNA ladder (Lane \#1); 50 ng DNA (Lane \#2); 25 ng DNA (Lane \#3); 12.5 ng DNA (Lane \#3); 6.25 ng DNA (Lane \#4); 3.125 ng DNA (Lane \#5). Gel band intensity is expressed as a ratio vs. Lane $\# 2$. The data show that the gel band intensity increases as the ln (DNA quantity in $\mathrm{ng}$ ) increases. $\mathrm{R}^{2}=0.9964$. 


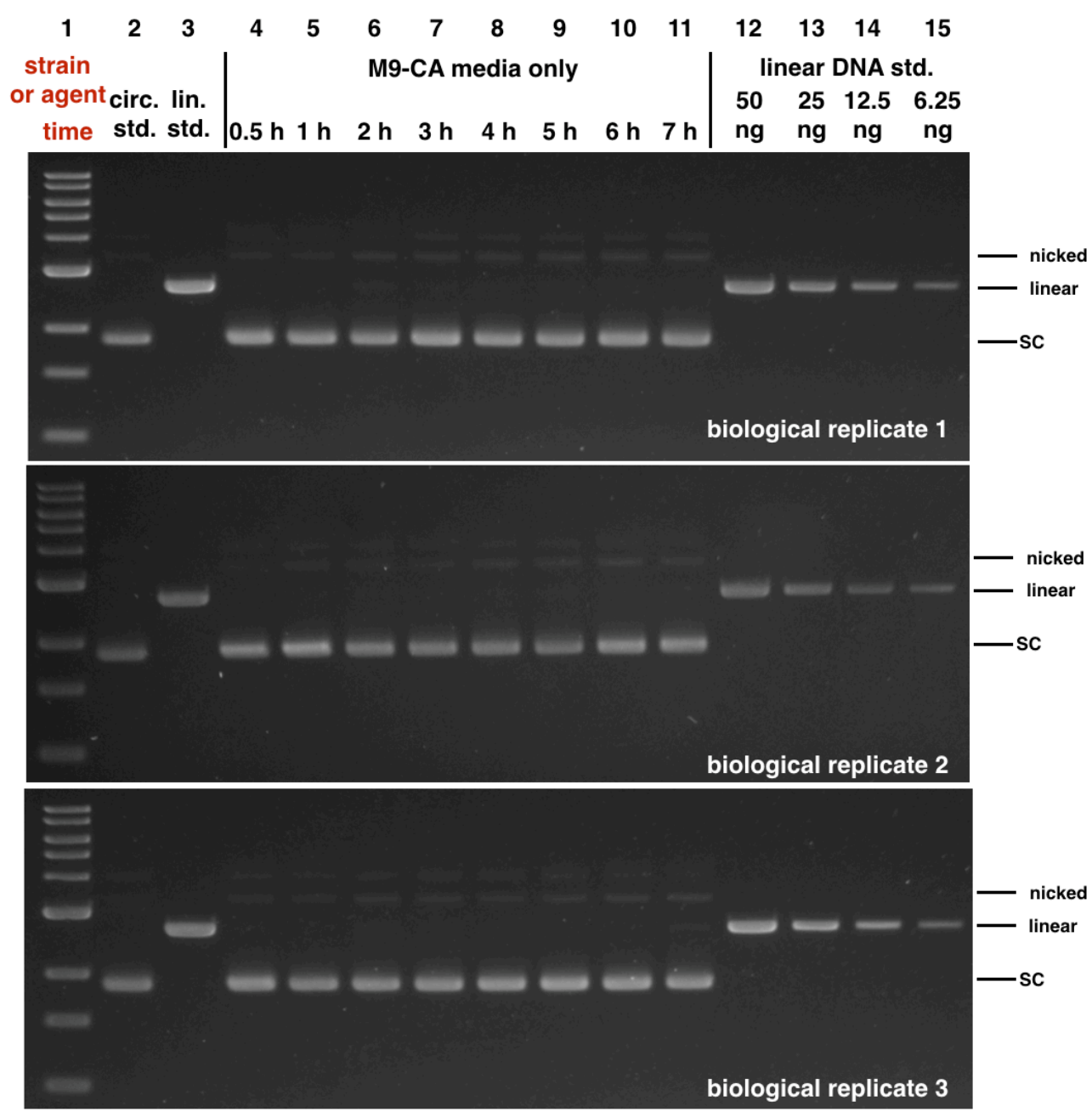

Fig. S3. DNA plasmid cleavage assay employing circular pUC19 DNA and M9-CA media. DNA ladder (Lane \#1); circular pUC19 DNA standard (Lane \#2); linearized pUC19 DNA standard (Lane \# 3); M9-CA media 0.5 h (Lane \#4), 1 h (Lane \#5), 2 h (Lane \#6), 3 h (Lane \#7), 4 h (Lane \#8), $5 \mathrm{~h}$ (Lane \#9), $6 \mathrm{~h}$ (Lane \#10), and $9 \mathrm{~h}$ (Lane \#11); linearized pUC19 DNA standard $50 \mathrm{ng}$ (Lane \#12), $25 \mathrm{ng}$ (Lane \#13), $12.5 \mathrm{ng}$ (Lane \#14), and 6.25 ng (Lane \#15). Conditions (Lane \#4-\#11): circular pUC19 DNA (7.7 $\mu \mathrm{M}$ in base pairs), M9-CA media, $37{ }^{\circ} \mathrm{C}$, reaction proceed for $0.5 \mathrm{~h}, 1 \mathrm{~h}, 2 \mathrm{~h}, 3 \mathrm{~h}, 4 \mathrm{~h}, 5 \mathrm{~h}, 6 \mathrm{~h}$, and $9 \mathrm{~h}$. The DNA was isolated, purified, and analyzed by native agarose gel electrophoresis $(90 \mathrm{~V}, 2 \mathrm{hr})$. The experiment was performed and analyzed in biological triplicates for quantification purpose. $\mathrm{SC}=$ supercoiled, nicked $=\mathrm{SSB}$, linear $=\mathrm{DSB}$. 


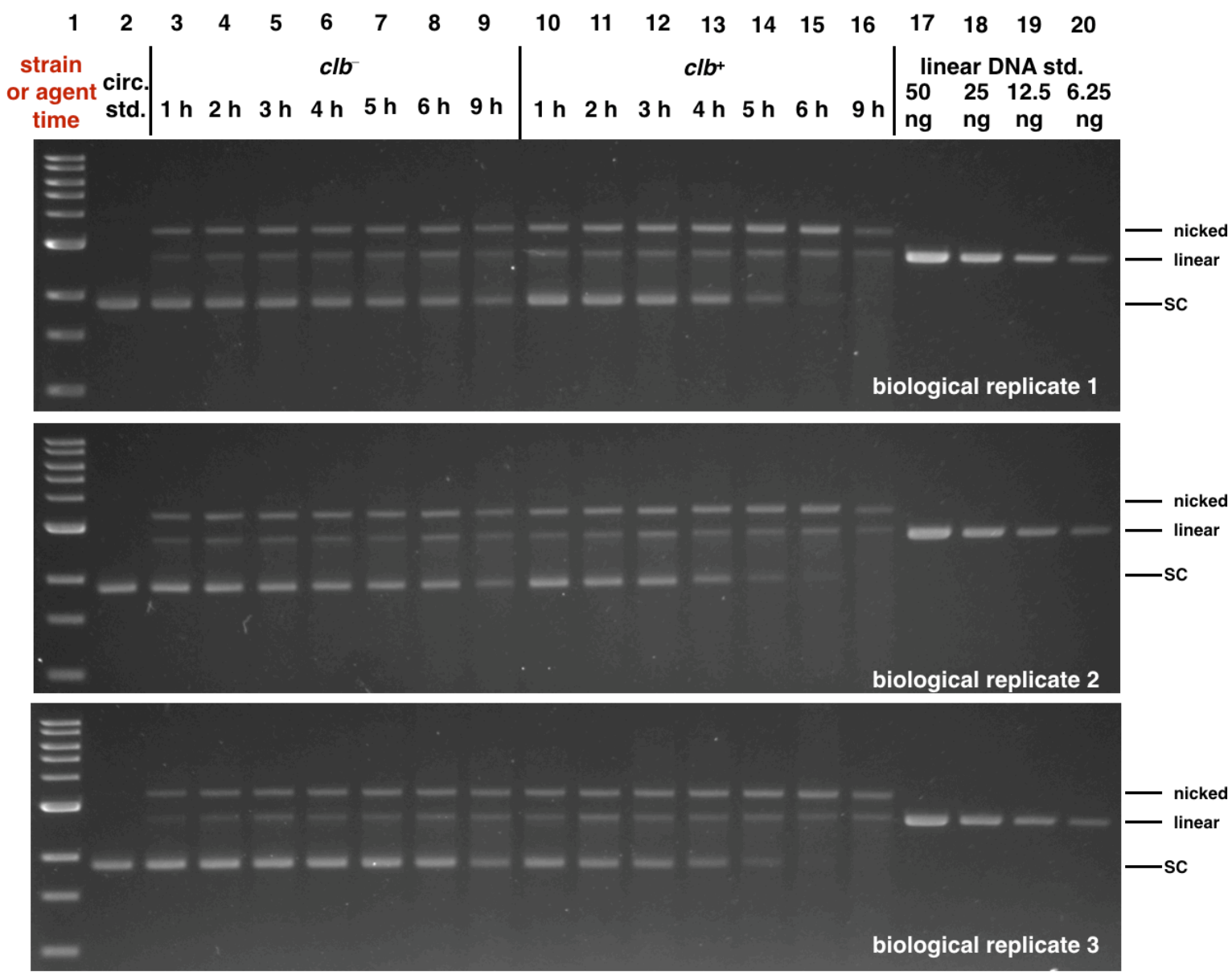

Fig. S4. DNA plasmid cleavage assay employing circular pUC19 DNA and $\mathrm{clb}^{-}$(or $\mathrm{clb}^{+}$) BW25113 E. coli. DNA ladder (Lane \#1); circular pUC19 DNA standard (Lane \#2); clb $^{-}$ BW25113 E. coli. $1 \mathrm{~h}$ (Lane \#3), 2 h (Lane \#4), 3 h (Lane \#5), 4 h (Lane \#6), 5 h (Lane \#7), $6 \mathrm{~h}$ (Lane \#8), and $9 \mathrm{~h}$ (Lane \#9); clb BW25113 E. coli. $1 \mathrm{~h}$ (Lane \#10), $2 \mathrm{~h}$ (Lane \#11), $3 \mathrm{~h}$ (Lane \#12), $4 \mathrm{~h}$ (Lane \#13), $5 \mathrm{~h}$ (Lane \#14), $6 \mathrm{~h}$ (Lane \#15), and $9 \mathrm{~h}$ (Lane \#16); linearized pUC19 DNA standard $50 \mathrm{ng}$ (Lane \#17), $25 \mathrm{ng}$ (Lane \#18), $12.5 \mathrm{ng}$ (Lane \#19), and 6.25 ng (Lane \#20). Conditions (Lane \#3-\#16): $\mathrm{clb}^{-}$BW25113 E. coli. (Lane \#3-\#9) or clb BW25113 E. coli. (Lane \#10-\#16), circular pUC19 DNA (7.7 $\mu \mathrm{M}$ in base pairs), M9-CA media, $37{ }^{\circ} \mathrm{C}$, reaction proceed for $1 \mathrm{~h}, 2 \mathrm{~h}, 4 \mathrm{~h}, 6 \mathrm{~h}$, and $9 \mathrm{~h}$. The DNA was isolated, purified, and analyzed by native agarose gel electrophoresis $(90 \mathrm{~V}, 2 \mathrm{hr})$. The experiment was performed and analyzed in biological triplicates for quantification purpose. $\mathrm{SC}=$ supercoiled, nicked $=\mathrm{SSB}$, linear $=\mathrm{DSB}$. 

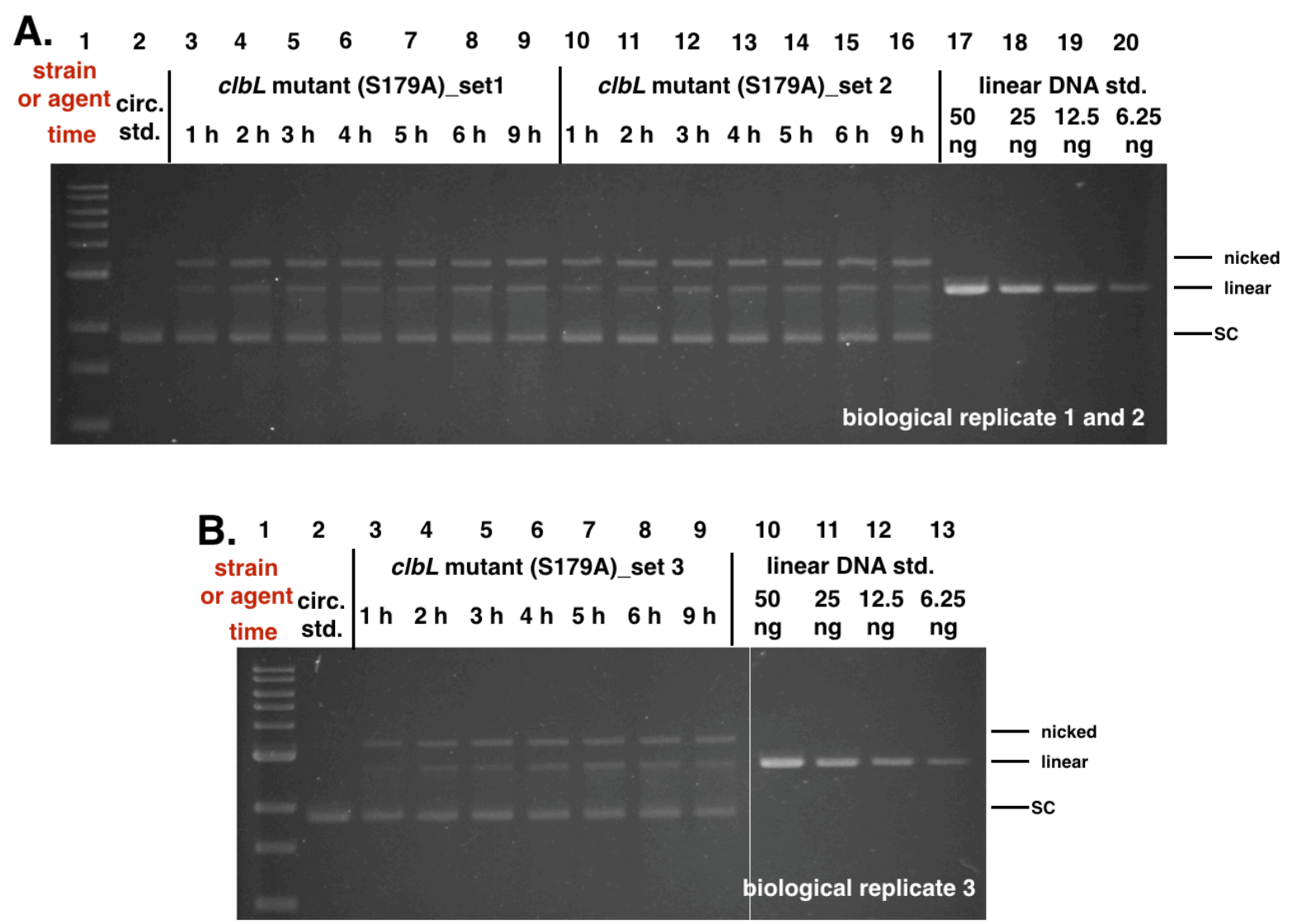

Fig. S5. DNA plasmid cleavage assay employing circular pUC19 DNA and $c l b L$ mutant (S179A) BW25113 E. coli. A. Biological replicate 1 and 2; B. Biological replicate 3. (Fig. S5A.) DNA ladder (Lane \#1); circular pUC19 DNA standard (Lane \#2); clbL point mutant (S179A) BW25113 E. coli set \#1, 1 h (Lane \#3), 2 h (Lane \#4), 3 h (Lane \#5), 4 h (Lane \#6), 5 h (Lane \#7), $6 \mathrm{~h}$ (Lane \#8), and $9 \mathrm{~h}$ (Lane \#9); clbL point mutant (S179A) set \#2, $1 \mathrm{~h}$ (Lane \#10), $2 \mathrm{~h}$ (Lane \#11), $3 \mathrm{~h}$ (Lane \#12), $4 \mathrm{~h}$ (Lane \#13), $5 \mathrm{~h}$ (Lane \#14), $6 \mathrm{~h}$ (Lane \#15), and $9 \mathrm{~h}$ (Lane \#16); linearized pUC19 DNA standard $50 \mathrm{ng}$ (Lane \#17), $25 \mathrm{ng}$ (Lane \#18), $12.5 \mathrm{ng}$ (Lane \#19), and 6.25 ng (Lane \#20). (Fig. S5B.) DNA ladder (Lane \#1); circular pUC19 DNA standard (Lane \#2); clbL point mutant (S179A) BW25113 E. coli set \#3, $1 \mathrm{~h}$ (Lane \#3), $2 \mathrm{~h}$ (Lane \#4), $3 \mathrm{~h}$ (Lane \#5), $4 \mathrm{~h}$ (Lane \#6), $5 \mathrm{~h}$ (Lane \#7), $6 \mathrm{~h}$ (Lane \#8), and $9 \mathrm{~h}$ (Lane \#9); linearized pUC19 DNA standard $50 \mathrm{ng}$ (Lane \#10), $25 \mathrm{ng}$ (Lane \#11), $12.5 \mathrm{ng}$ (Lane \#12), and $6.25 \mathrm{ng}$ (Lane \#13). Conditions (Fig. S5A. Lane \#3-\#16, and Fig. S5B. Lane \#3-\#9): clbL point mutant (S179A) BW25113 E. coli, circular pUC19 DNA (7.7 $\mu \mathrm{M}$ in base pairs), M9-CA media, $37^{\circ} \mathrm{C}$, reaction proceed for $1 \mathrm{~h}, 2 \mathrm{~h}, 4 \mathrm{~h}, 6 \mathrm{~h}$, and 9 h. The DNA was isolated, purified, and analyzed by native agarose gel electrophoresis $(90 \mathrm{~V}, 2$ $\mathrm{hr})$. The experiment was performed and analyzed in biological triplicates for quantification purpose. $\mathrm{SC}=$ supercoiled, nicked $=\mathrm{SSB}$, linear $=\mathrm{DSB}$. 


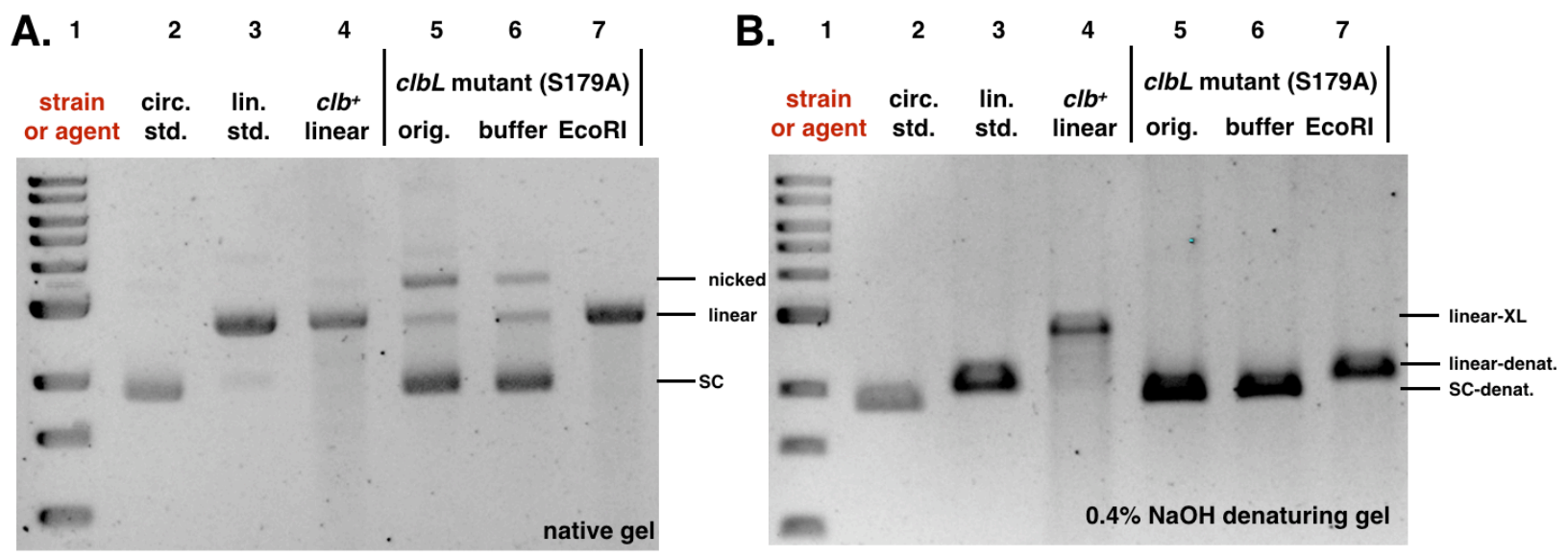

Fig. S6. Plasmid DNA linearization test employing circular pUC19 DNA isolated from coculture with clbL point mutant $(\mathrm{S179A}) \mathrm{BW} 25113 \mathrm{E}$. coli. A. Native gel. B. $0.4 \% \mathrm{NaOH}$ denaturing gel. The cross-linked linearized pUC19 isolated from co-culture with $c l b^{+} \mathrm{BW} 25113$ E. coli was used as a positive control. DNA ladder (Lane \#1); circular pUC19 DNA (Lane \#2); linearized pUC19 DNA (Lane \#3); linearized pUC19 DNA co-cultured with $\mathrm{clb}^{+} \mathrm{BW} 25113 \mathrm{E}$. coli (Lane \#4); circular pUC19 DNA isolated from co-culture with clbL point mutant (S179A) BW25113 E. coli (Lane \#5), reacted with buffer (Lane \#6), reacted with EcoRI restriction enzyme (Lane \#7). Conditions (Lane \#4): linearized pUC19 DNA, clb BW25113 E. coli, M9-CA media, $4 \mathrm{~h}$ at $37^{\circ} \mathrm{C}$. Conditions (Lanes \#5-\#7): circular pUC19 DNA isolated from co-culture with $c l b L$ point mutant (S179A) BW25113 E. coli in M9-CA media for $4 \mathrm{~h}$ at $37{ }^{\circ} \mathrm{C}$ (Lane \# 5); the DNA $\left(15.4 \mu \mathrm{M}\right.$ base pair) was reacted with CutSmart Buffer ${ }^{\circledR}$ (New England Biolabs $\left.{ }^{\circledR}\right), \mathrm{pH} 7.9$, at 37 ${ }^{\circ} \mathrm{C}$ for $30 \mathrm{~min}$ (Lane \#6); the DNA $(15.4 \mu \mathrm{M}$ base pair) was reacted with 20 units of EcoRI-HF restriction enzyme in CutSmart Buffer ${ }^{\circledR}$ (New England Biolabs ${ }^{\circledR}$ ), $\mathrm{pH} 7.9$, at $37^{\circ} \mathrm{C}$ for $30 \mathrm{~min}$ (Lane \#7). The DNA was isolated and analyzed by either (Fig. S6A) $0 \% \mathrm{NaOH}$ native agarose gel electrophoresis, or (Fig. S6B) $0.4 \% \mathrm{NaOH}$ denature agarose gel electrophoresis ( $90 \mathrm{~V}, 1.5 \mathrm{~h}$ ). $\mathrm{SC}=$ supercoiled, nicked $=\mathrm{SSB}$, linear $=\mathrm{DSB}, \mathrm{SC}-$ denat. $=$ supercoiled DNA in denaturing form, linear-denat. $=\mathrm{DSB} /$ linearized $\mathrm{DNA}$ in denaturing form, linear-XL $=\mathrm{DSB} /$ linearized DNA crosslinked by colibactin. 


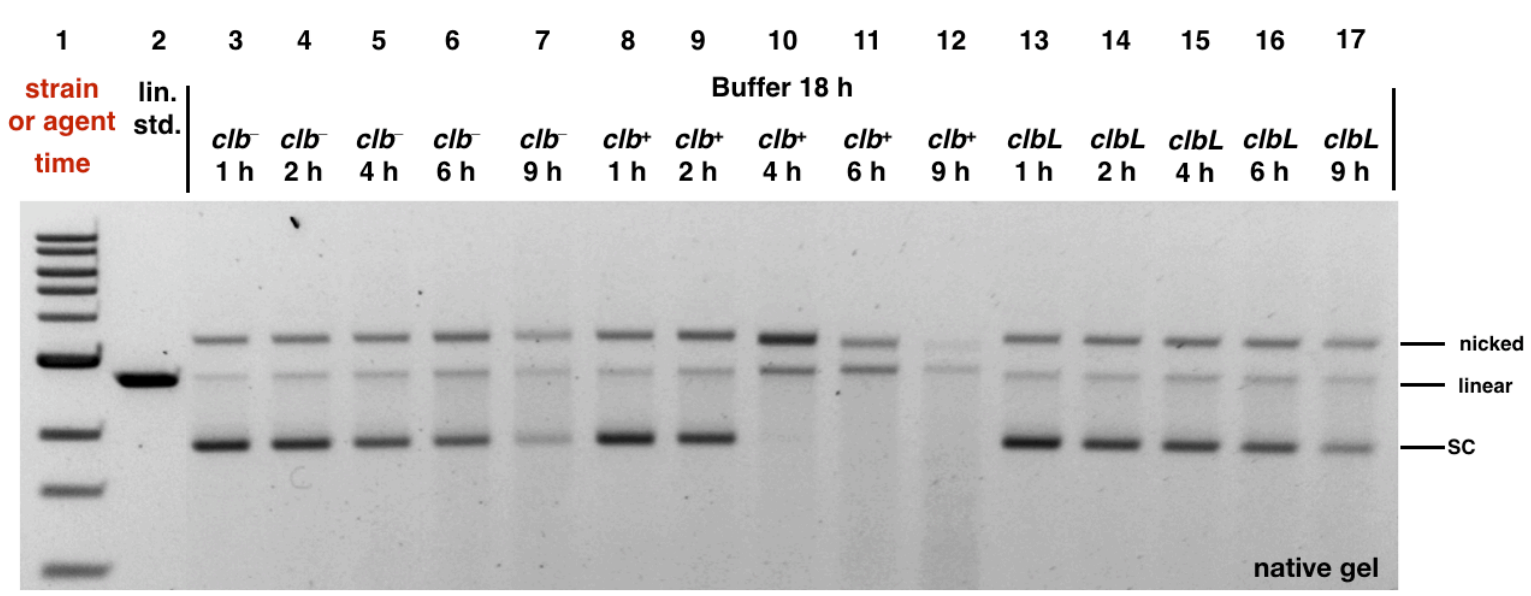

Fig. S7. Plasmid DNA stability test employing circular pUC19 DNA isolated from co-culture with $\boldsymbol{c l b}, \boldsymbol{c l b}{ }^{+}$, or $\boldsymbol{c l b L}$ mutant (S179A) BW25113 E. coli. DNA ladder (Lane \#1); linearized pUC19 DNA standard (Lane \# 2); post buffer-reacted with DNA isolated from $\mathrm{clb}^{-}$BW25113 E. coli $1 \mathrm{~h}$ (Lane \#3), $2 \mathrm{~h}$ (Lane \#4), $4 \mathrm{~h}$ (Lane \#5), $6 \mathrm{~h}$ (Lane \#6), and $9 \mathrm{~h}$ (Lane \#7); post bufferreacted with DNA isolated from $\mathrm{clb}^{+} \mathrm{BW} 25113 \mathrm{E}$. coli $1 \mathrm{~h}$ (Lane \#8), $2 \mathrm{~h}$ (Lane \#9), $4 \mathrm{~h}$ (Lane $\# 10$ ), $6 \mathrm{~h}$ (Lane \#11), and $9 \mathrm{~h}$ (Lane \#12); post buffer-reacted with DNA isolated from clbL point mutant (S179A) BW25113 E. coli $1 \mathrm{~h}$ (Lane \#13), $2 \mathrm{~h}$ (Lane \#14), $4 \mathrm{~h}$ (Lane \#15), $6 \mathrm{~h}$ (Lane \#16), and $9 \mathrm{~h}$ (Lane \#17). Conditions (Lane \#3-\#17): NEBuffer 3.1 ${ }^{\circledR}$ (New England Biolabs ${ }^{\circledR}$ ), pH 7.9, at $37^{\circ} \mathrm{C}$ for $18 \mathrm{~h}, 50 \mu \mathrm{g}$ of DNA isolated from reacting with $\mathrm{clb}^{-} \mathrm{BW} 25113 \mathrm{E}$. coli for 1 to 9 hours (Lane \#3-\#7), reacting with $\mathrm{clb}^{+}$BW25113 E. coli for 1 to 9 hours (Lane \#8-\#12), and reacting with $c l b L$ point mutant (S179A) BW25113 E. coli for 1 to 9 hours (Lane \#13-\#17). The DNA was not further purified and was directly analyzed by native agarose gel electrophoresis $(90 \mathrm{~V}, 2$ h). $\mathrm{SC}=$ supercoiled, nicked $=\mathrm{SSB}$, linear $=\mathrm{DSB}$. 


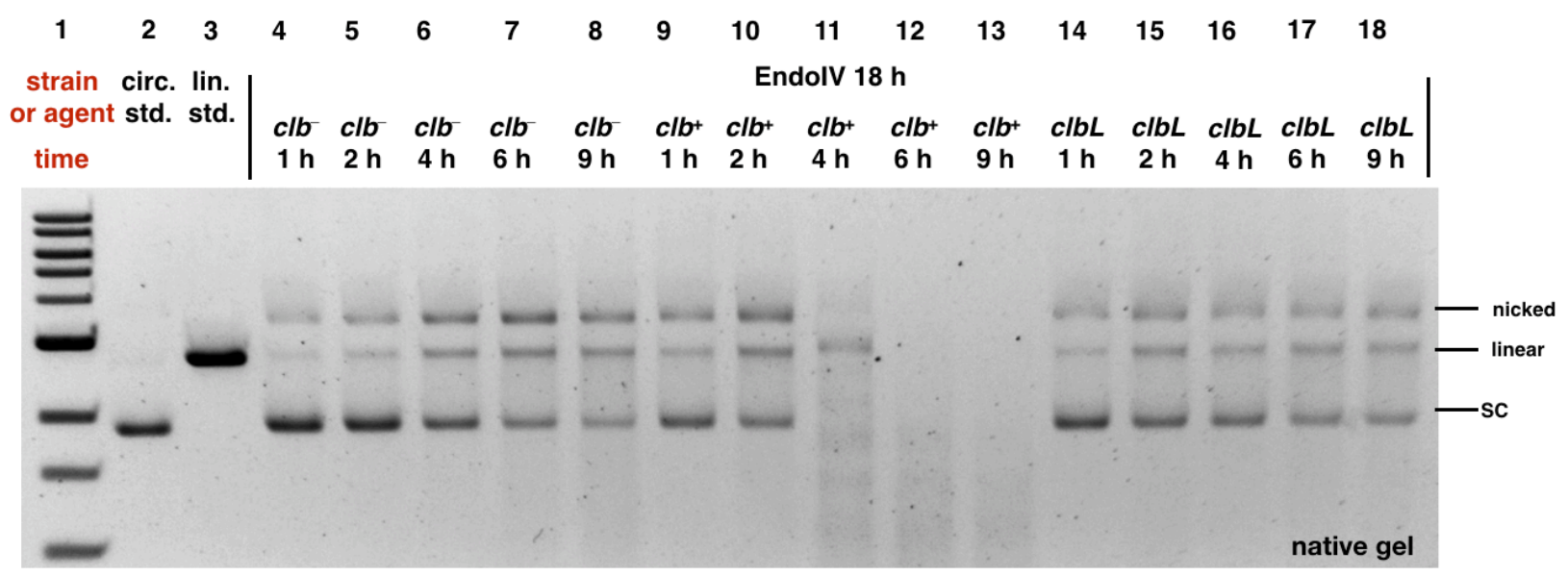

Fig. S8. Plasmid DNA Endonuclease IV stability test employing circular pUC19 DNA isolated from co-culture with $c l b, c l b^{+}$, or $c l b L$ mutant (S179A) BW25113 E. coli. The Endonuclease IV selectively cleaves DNA 5' apurinic sites. DNA ladder (Lane \#1); circular pUC19 DNA standard (Lane \#2); linearized pUC19 DNA standard (Lane \# 3); EndoIV-reacted with DNA isolated from $\mathrm{clb}^{-}$BW25113 E. coli $1 \mathrm{~h}$ (Lane \#4), $2 \mathrm{~h}$ (Lane \#5), $4 \mathrm{~h}$ (Lane \#6), $6 \mathrm{~h}$ (Lane \#7), and $9 \mathrm{~h}$ (Lane \#8); EndoIV-reacted with DNA isolated from $\mathrm{clb}^{+} \mathrm{BW} 25113 \mathrm{E}$. coli $1 \mathrm{~h}$ (Lane \#9), $2 \mathrm{~h}$ (Lane \#10), $4 \mathrm{~h}$ (Lane \#11), $6 \mathrm{~h}$ (Lane \#12), and $9 \mathrm{~h}$ (Lane \#13); post buffer-reacted with DNA isolated from $c l b L$ point mutant (S179A) BW25113 E. coli $1 \mathrm{~h}$ (Lane \#14), $2 \mathrm{~h}$ (Lane \#15), $4 \mathrm{~h}$ (Lane \#16), $6 \mathrm{~h}$ (Lane \#17), and $9 \mathrm{~h}$ (Lane \#18). Conditions (Lane \#4-\#18): 20 units of Endonuclease IV (New England Biolabs $\left.{ }^{\circledR}\right)$, NEBuffer 3.1 ${ }^{\circledR}$ (New England Biolabs ${ }^{\circledR}$ ), pH 7.9, at $37^{\circ} \mathrm{C}$ for $18 \mathrm{~h}, 50 \mu \mathrm{g}$ of DNA isolated from reacting with $\mathrm{clb}^{-} \mathrm{BW} 25113 \mathrm{E}$. coli for 1 to 9 hours (Lane \#4-\#8), reacting with $\mathrm{clb}^{+}$BW25113 E. coli from 1 to 9 hours (Lane \#9-\#13), and reacting with $c l b L$ point mutant (S179A) BW25113 E. coli for 1 to 9 hours (Lane \#14-\#18). The DNA was not further purified and was directly analyzed by native agarose gel electrophoresis $(90 \mathrm{~V}, 2$ h). $\mathrm{SC}=$ supercoiled, nicked $=\mathrm{SSB}$, linear $=\mathrm{DSB}$. 


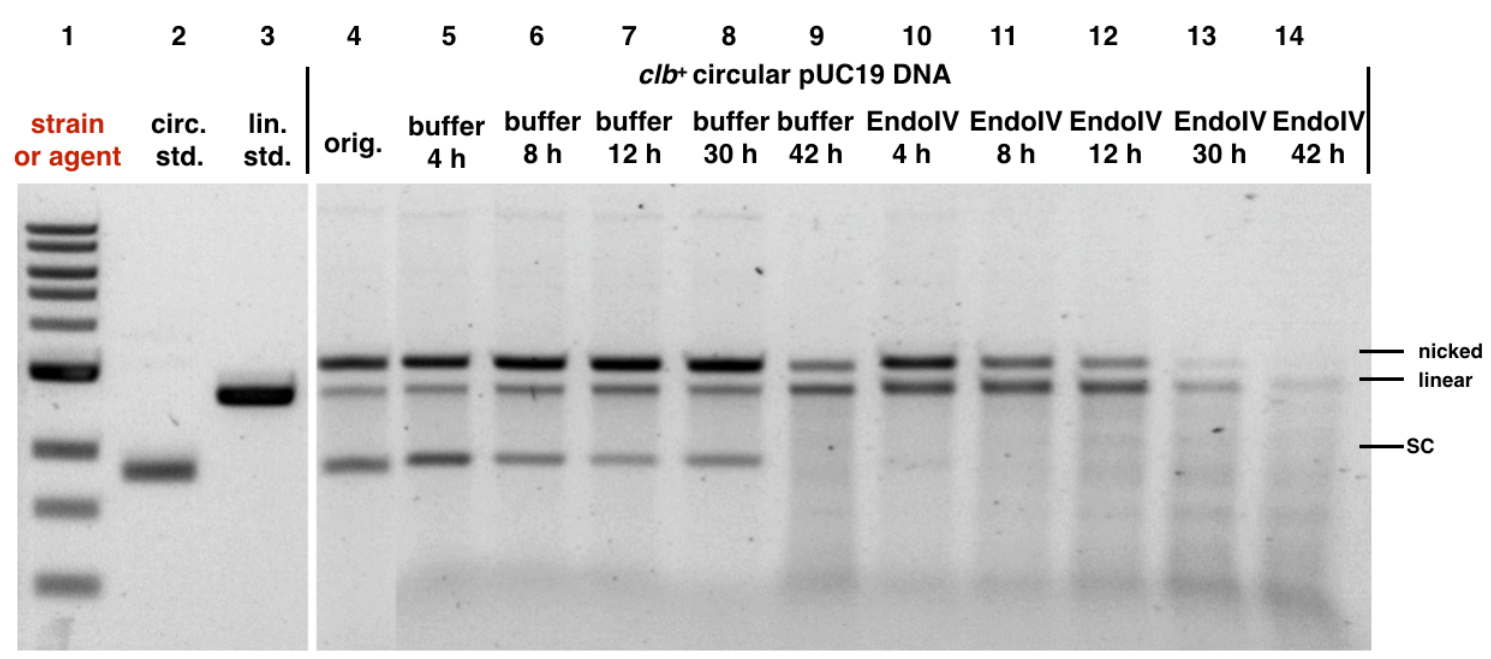

Fig. S9. Plasmid DNA Endonuclease IV stability test employing circular pUC19 DNA isolated from co-culture with $\mathrm{clb}^{+} \mathbf{B W 2 5 1 1 3} \mathbf{E}$. coli. Endonuclease IV selectively cleaves DNA $5^{\prime}$ to apurinic sites. DNA ladder (Lane \#1); circular pUC19 DNA standard (Lane \#2); linearized pUC19 DNA standard (Lane \#3); circular pUC19 DNA isolated from co-culture with $c b^{+}$ BW25113 E. coli (Lane \#4), reacted with buffer only for $4 \mathrm{~h}$ (Lane \#5), $8 \mathrm{~h}$ (Lane \#6), $12 \mathrm{~h}$ (Lane \#7), $30 \mathrm{~h}$ (Lane \#8), and $42 \mathrm{~h}$ (Lane \#9); circular pUC19 DNA isolated from co-culture with $\mathrm{clb}^{+}$ BW25113 E. coli reacted with Endonuclease IV for $4 \mathrm{~h}$ (Lane \#10), $8 \mathrm{~h}$ (Lane \#11), $12 \mathrm{~h}$ (Lane \#12), $30 \mathrm{~h}$ (Lane \#13), and $42 \mathrm{~h}$ (Lane \#14). Conditions (Lanes \#4-\#14): circular pUC19 DNA isolated from co-culture with $\mathrm{clb}^{+} \mathrm{BW} 25113 \mathrm{E}$. coli in M9-CA media for $4 \mathrm{~h}$ at $37^{\circ} \mathrm{C}$ (Lane \#4); the DNA $\left(3.9 \mu \mathrm{M}\right.$ base pair) was reacted with NEBuffer 3.1® (New England Biolabs $\left.{ }^{\circledR}\right), \mathrm{pH}$ 7.9, at $37^{\circ} \mathrm{C}$ for $4 \mathrm{~h}, 8 \mathrm{~h}, 12 \mathrm{~h}, 30 \mathrm{~h}$, or $42 \mathrm{~h}$ (Lanes $\left.\# 5-\# 9\right)$; the DNA ( $3.9 \mu \mathrm{M}$ base pair) was reacted with 20 units of Endonuclease IV in NEBuffer 3.1 ${ }^{\circledR}$ (New England Biolabs ${ }^{\circledR}$ ), pH 7.9, at $37^{\circ} \mathrm{C}$ for $4 \mathrm{~h}, 8 \mathrm{~h}, 12 \mathrm{~h}, 30 \mathrm{~h}$, or $42 \mathrm{~h}$ (Lanes \#10-\#14). The DNA was not re-purified and was directly analyzed by native agarose gel electrophoresis $(90 \mathrm{~V}, 2 \mathrm{~h})$. SC $=$ supercoiled, nicked $=\mathrm{SSB}$, linear $=$ DSB. 


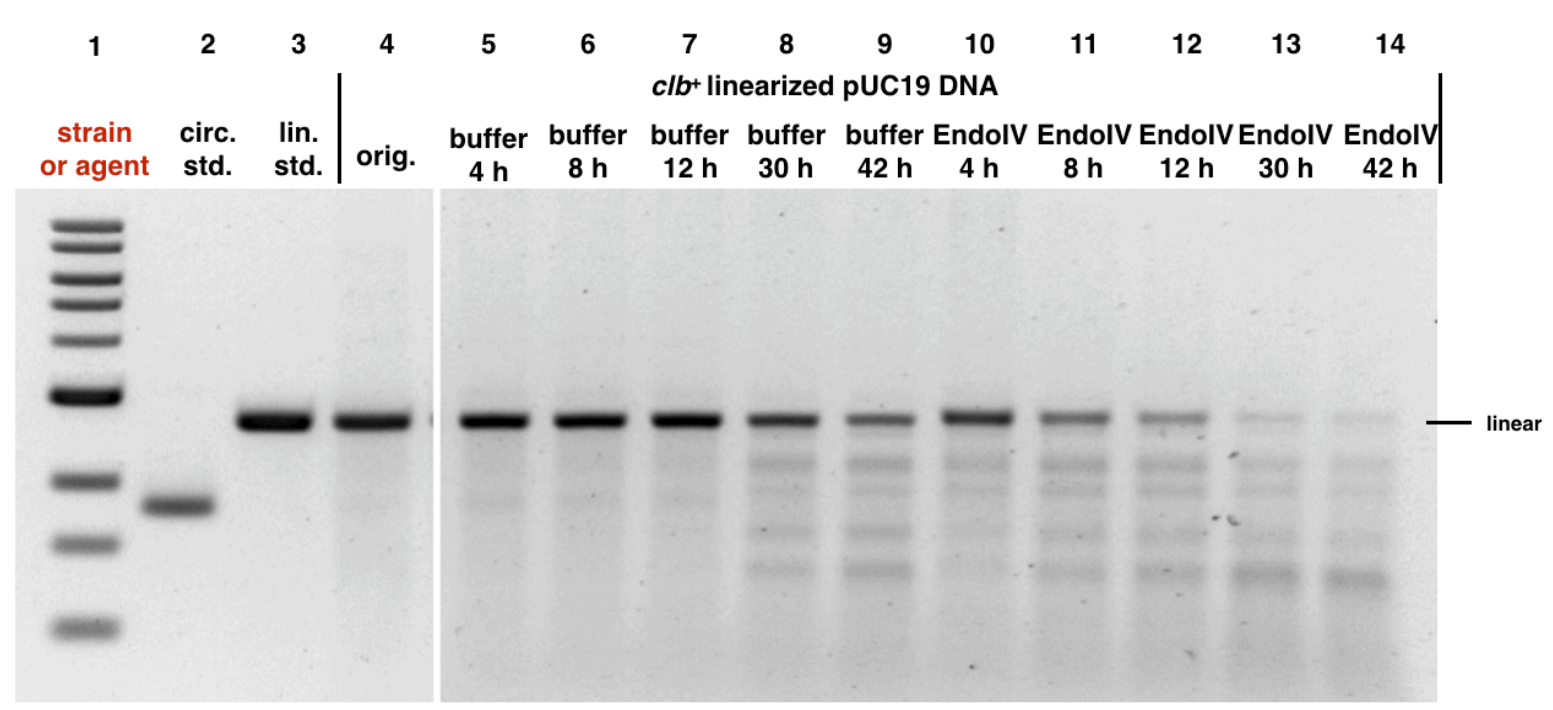

Fig. S10. Plasmid DNA Endonuclease IV stability test employing linearized pUC19 DNA isolated from co-culture with $\mathrm{clb}^{+} \mathbf{B W 2 5 1 1 3} \mathbf{E}$. coli. Endonuclease IV selectively cleaves DNA $5^{\prime}$ to apurinic sites. DNA ladder (Lane \#1); circular pUC19 DNA standard (Lane \#2); linearized pUC19 DNA standard (Lane \#3); linearized pUC19 DNA isolated from co-culture with $\mathrm{clb}^{+}$ BW25113 E. coli (Lane \#4), reacted with buffer only for $4 \mathrm{~h}$ (Lane \#5), $8 \mathrm{~h}$ (Lane \#6), $12 \mathrm{~h}$ (Lane $\# 7$ ), $30 \mathrm{~h}$ (Lane \#8), and $42 \mathrm{~h}$ (Lane \#9); linearized pUC19 DNA isolated from co-culture with $\mathrm{clb}^{+}$ BW25113 E. coli reacted with Endonuclease IV for $4 \mathrm{~h}$ (Lane \#10), $8 \mathrm{~h}$ (Lane \#11), $12 \mathrm{~h}$ (Lane \#12), $30 \mathrm{~h}$ (Lane \#13), and $42 \mathrm{~h}$ (Lane \#14). Conditions (Lanes \#4-\#14): linearized pUC19 DNA isolated from co-culture with $\mathrm{clb}^{+} \mathrm{BW} 25113 \mathrm{E}$. coli in M9-CA media for $4 \mathrm{~h}$ at $37^{\circ} \mathrm{C}$ (Lane \#4); the DNA $\left(3.9 \mu \mathrm{M}\right.$ base pair) was reacted with NEBuffer 3.1® (New England Biolabs $\left.{ }^{\circledR}\right), \mathrm{pH}$ 7.9, at $37^{\circ} \mathrm{C}$ for $4 \mathrm{~h}, 8 \mathrm{~h}, 12 \mathrm{~h}, 30 \mathrm{~h}$, or $42 \mathrm{~h}$ (Lanes \#5-\#9); the DNA (3.9 $\mu \mathrm{M}$ base pair) was reacted with 20 units of Endonuclease IV in NEBuffer 3.1 ${ }^{\circledR}$ (New England Biolabs ${ }^{\circledR}$ ), pH 7.9, at $37{ }^{\circ} \mathrm{C}$ for $4 \mathrm{~h}, 8 \mathrm{~h}, 12 \mathrm{~h}, 30 \mathrm{~h}$, or $42 \mathrm{~h}$ (Lanes \#10-\#14). The DNA was not re-purified and was directly analyzed by native agarose gel electrophoresis $(90 \mathrm{~V}, 2 \mathrm{~h})$. Linear $=$ linearized DNA cross-linked by colibactin 


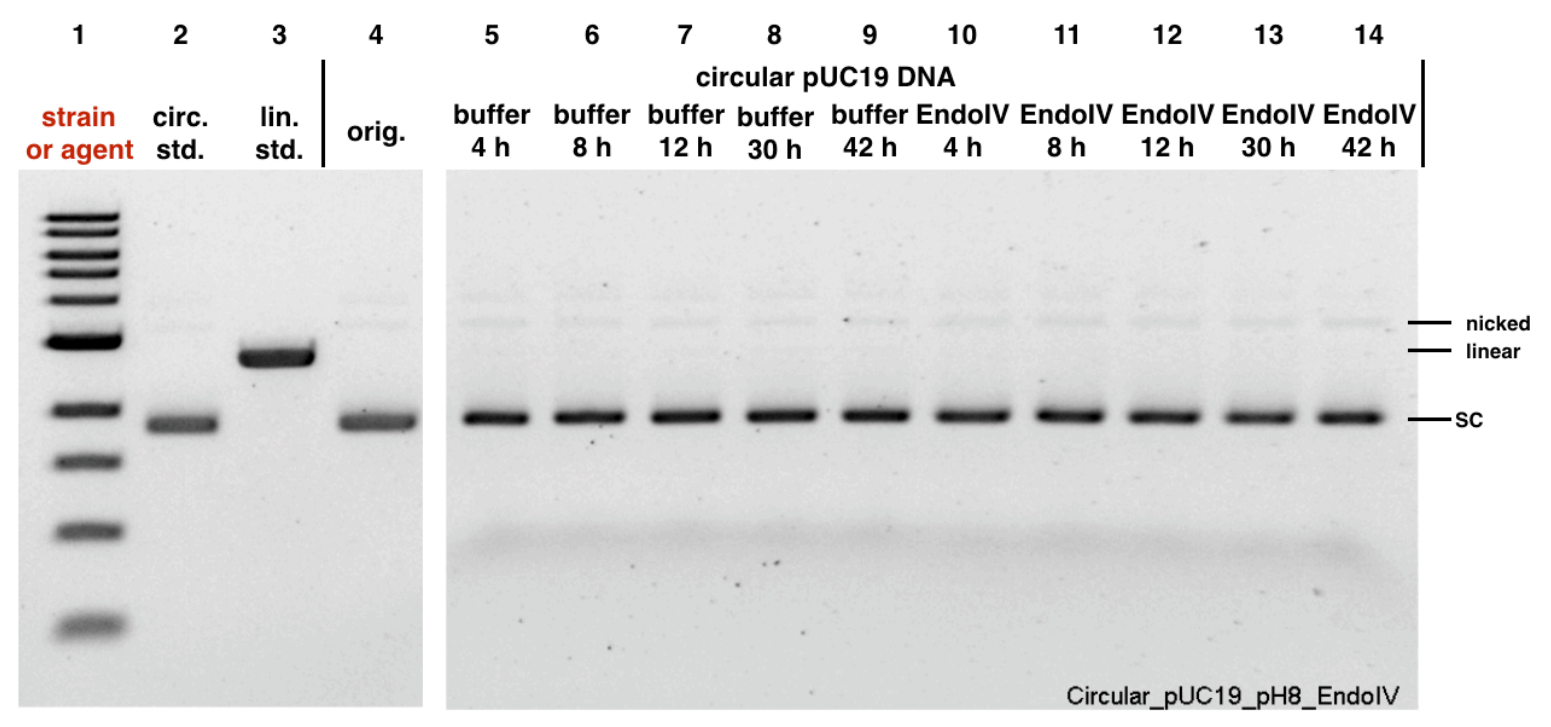

Fig. S11. Plasmid DNA Endonuclease IV stability test employing circular pUC19 DNA. Endonuclease IV selectively cleaves DNA 5' to apurinic sites. DNA ladder (Lane \#1); circular pUC19 DNA standard (Lane \#2); linearized pUC19 DNA standard (Lane \#3); circular pUC19 DNA original sample (Lane \#4), reacted with buffer only for $4 \mathrm{~h}$ (Lane \#5), $8 \mathrm{~h}$ (Lane \#6), $12 \mathrm{~h}$ (Lane \#7), $30 \mathrm{~h}$ (Lane \#8), and $42 \mathrm{~h}$ (Lane \#9); circular pUC19 DNA reacted with Endonuclease IV for $4 \mathrm{~h}$ (Lane \#10), $8 \mathrm{~h}$ (Lane \#11), $12 \mathrm{~h}$ (Lane \#12), $30 \mathrm{~h}$ (Lane \#13), and $42 \mathrm{~h}$ (Lane \#14). Conditions (Lanes \#5-\#14): circular pUC19 DNA (3.9 $\mu \mathrm{M}$ base pair) was reacted with NEBuffer 3.1® (New England Biolabs ${ }^{\circledR}$ ), pH 7.9, at $37{ }^{\circ} \mathrm{C}$ for 4 h, 8 h, 12 h, 30 h, or 42 h (Lanes \#5-\#9); the DNA (3.9 $\mu \mathrm{M}$ base pair) was reacted with 20 units of Endonuclease IV in NEBuffer 3.1® (New England Biolabs ${ }^{\circledR}$ ), pH 7.9, at $37{ }^{\circ} \mathrm{C}$ for 4 h, 8 h, 12 h, 30 h, or 42 h (Lanes \#10-\#14). The DNA was not re-purified and was directly analyzed by native agarose gel electrophoresis $(90 \mathrm{~V}, 2$ h). $\mathrm{SC}=$ supercoiled, nicked $=\mathrm{SSB}$, linear $=\mathrm{DSB}$. 


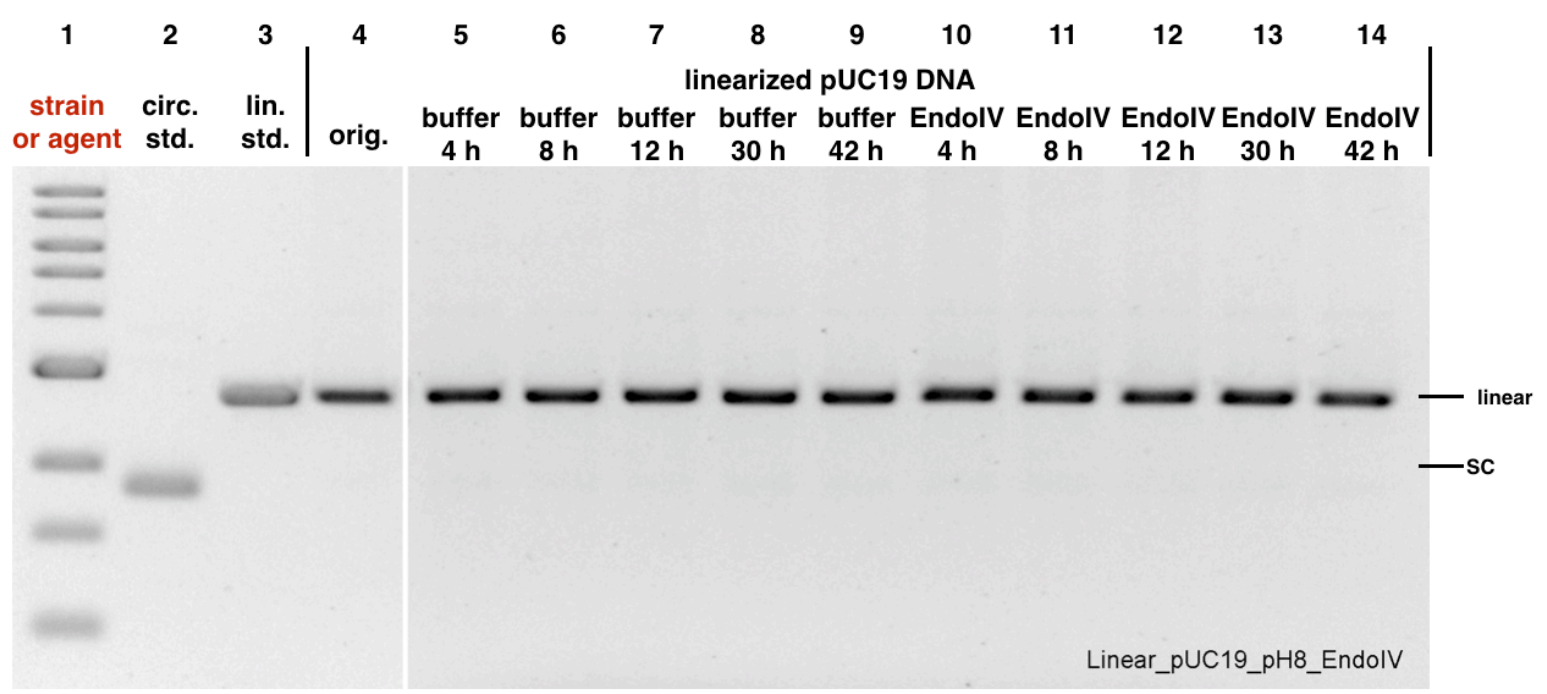

Fig. S12. Plasmid DNA Endonuclease IV stability test employing linearized pUC19 DNA. Endonuclease IV selectively cleaves DNA 5' to apurinic sites. DNA ladder (Lane \#1); circular pUC19 DNA standard (Lane \#2); linearized pUC19 DNA standard (Lane \# 3); linearized pUC19 DNA control (Lane \#4), reacted with buffer only for $4 \mathrm{~h}$ (Lane \#5), $8 \mathrm{~h}$ (Lane \#6), $12 \mathrm{~h}$ (Lane \#7), $30 \mathrm{~h}$ (Lane \#8), and $42 \mathrm{~h}$ (Lane \#9); circular pUC19 DNA reacted with Endonuclease IV for $4 \mathrm{~h}$ (Lane \#10), $8 \mathrm{~h}$ (Lane \#11), $12 \mathrm{~h}$ (Lane \#12), $30 \mathrm{~h}$ (Lane \#13), and $42 \mathrm{~h}$ (Lane \#14). Conditions (Lanes \#5-\#14): linearized pUC19 DNA (3.9 $\mu \mathrm{M}$ base pair) was reacted with NEBuffer $3.1{ }^{\circledR}$ (New England Biolabs ${ }^{\circledR}$ ), $\mathrm{pH} 7.9$, at $37^{\circ} \mathrm{C}$ for $4 \mathrm{~h}, 8 \mathrm{~h}, 12 \mathrm{~h}, 30 \mathrm{~h}$, or $42 \mathrm{~h}$ (Lanes \#5-\#9); the DNA (3.9 $\mu \mathrm{M}$ base pair) was reacted with 20 units of Endonuclease IV in NEBuffer $3.1{ }^{\circledR}$ (New England Biolabs $\left.{ }^{\circledR}\right), \mathrm{pH} 7.9$, at $37^{\circ} \mathrm{C}$ for $4 \mathrm{~h}, 8 \mathrm{~h}, 12 \mathrm{~h}, 30 \mathrm{~h}$, or $42 \mathrm{~h}$ (Lanes \#10-\#14). The DNA was not re-purified and was directly analyzed by native agarose gel electrophoresis $(90 \mathrm{~V}, 2 \mathrm{~h})$. $\mathrm{SC}=$ supercoiled, linear $=$ linearized DNA. 


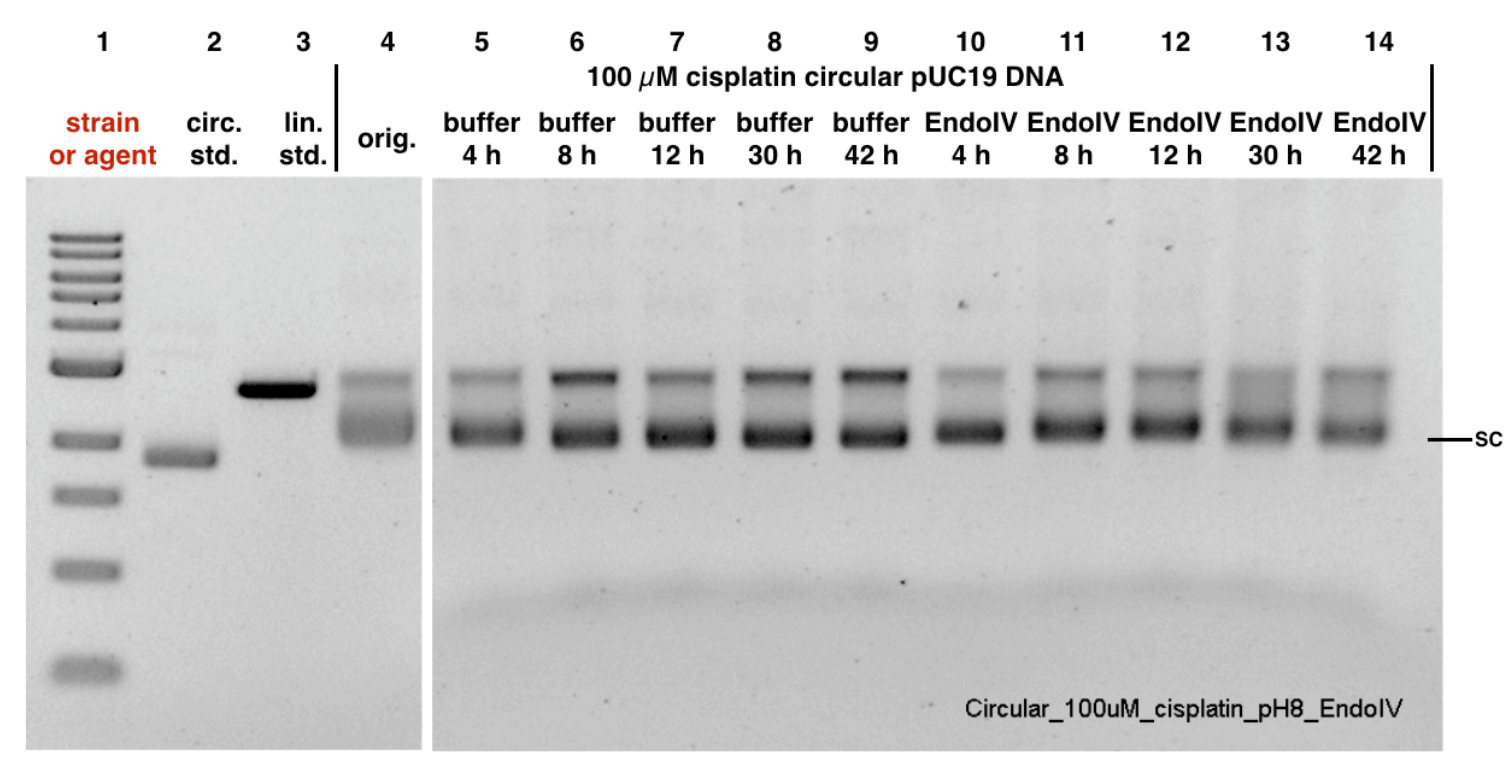

Fig. S13. Plasmid DNA Endonuclease IV stability test employing circular pUC19 DNA thathas been previously treated with $100 \mu \mathrm{M}$ cisplatin. Endonuclease IV selectively cleaves DNA 5' to apurinic sites. DNA ladder (Lane \#1); circular pUC19 DNA control (Lane \#2); linearized pUC19 DNA standard (Lane \#3); circular pUC19 DNA $100 \mu \mathrm{M}$ cisplatin, pH 5.0, $3 \mathrm{~h}$ (Lane \#4), $100 \mu \mathrm{M}$ cisplatin-treated circular pUC10 DNA reacted with buffer only for $4 \mathrm{~h}$ (Lane \#5), $8 \mathrm{~h}$ (Lane \#6), $12 \mathrm{~h}$ (Lane \#7), $30 \mathrm{~h}$ (Lane \#8), and $42 \mathrm{~h}$ (Lane \#9); circular pUC19 DNA reacted with Endonuclease IV for $4 \mathrm{~h}$ (Lane \#10), $8 \mathrm{~h}$ (Lane \#11), $12 \mathrm{~h}$ (Lane \#12), $30 \mathrm{~h}$ (Lane $\# 13$ ), and $42 \mathrm{~h}$ (Lane \#14). Conditions (Lanes \#4-\#14): circular pUC19 DNA (15.4 $\mu \mathrm{M}$ base pair) that has been reacted with $100 \mu \mathrm{M}$ cisplatin in $10 \mathrm{mM}$ sodium citrate buffer, $\mathrm{pH} 5.0$ for $4 \mathrm{~h}$ at 37 ${ }^{\circ} \mathrm{C}$ (Lane \#4); the DNA (3.9 $\mu \mathrm{M}$ base pair) was further reacted with NEBuffer 3.1 ${ }^{\circledR}$ (New England Biolabs $\left.{ }^{\circledR}\right), \mathrm{pH} 7.9$, at $37^{\circ} \mathrm{C}$ for $4 \mathrm{~h}, 8 \mathrm{~h}, 12 \mathrm{~h}, 30 \mathrm{~h}$, or $42 \mathrm{~h}$ (Lanes \#5-\#9); the DNA (3.9 $\mu \mathrm{M}$ base pair) was further reacted with 20 units of Endonuclease IV in NEBuffer 3.1® (New England Biolabs ${ }^{\circledR}$ ), $\mathrm{pH} 7.9$, at $37^{\circ} \mathrm{C}$ for $4 \mathrm{~h}, 8 \mathrm{~h}, 12 \mathrm{~h}, 30 \mathrm{~h}$, or $42 \mathrm{~h}$ (Lanes \#10 \#14). The DNA was not re-purified and was directly analyzed by native agarose gel electrophoresis $(90 \mathrm{~V}, 2 \mathrm{~h}) . \mathrm{SC}=$ supercoiled DNA cross-linked by cisplatin. 


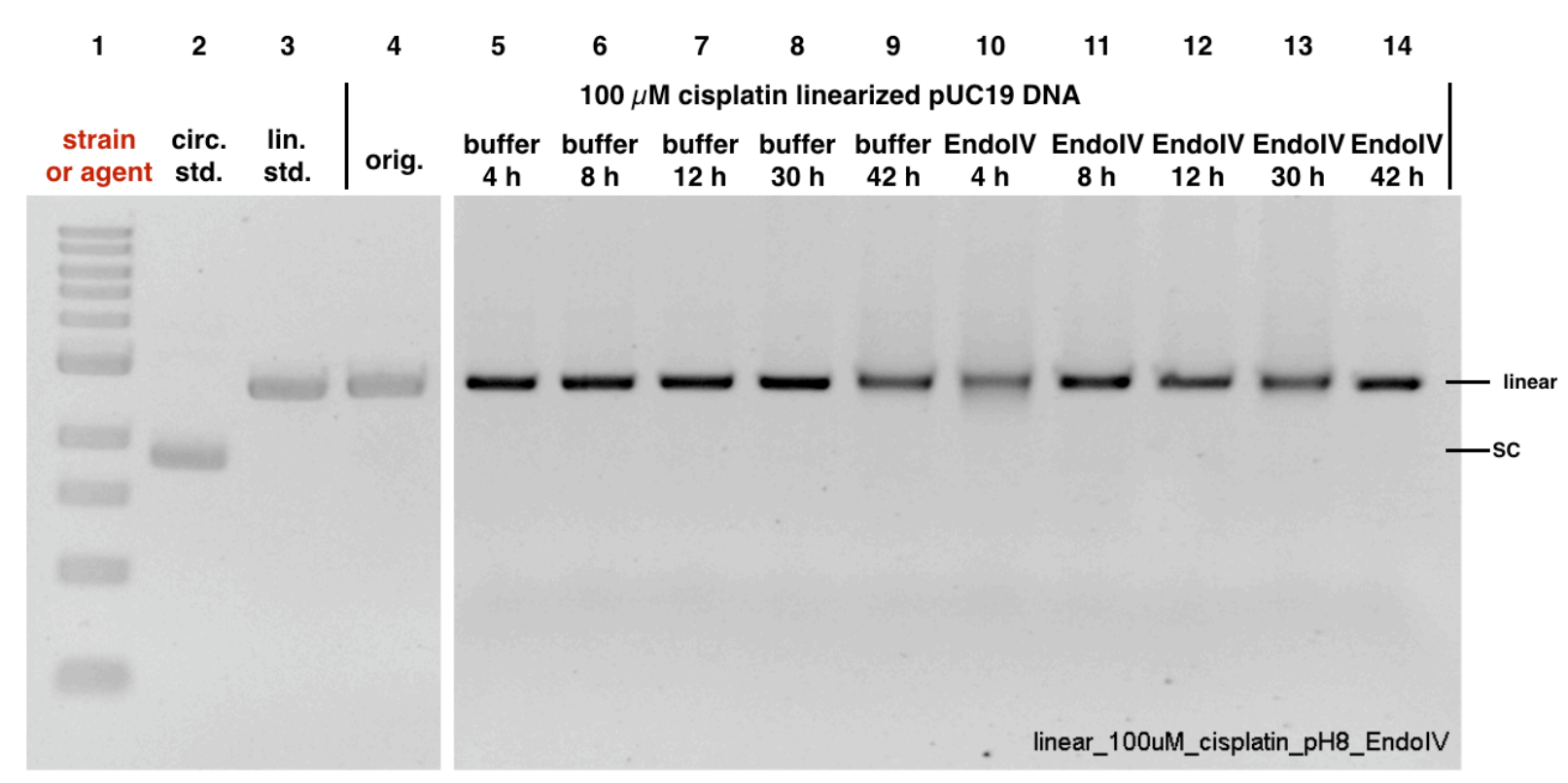

Fig. S14. Plasmid DNA Endonuclease IV stability test employing linearized pUC19 DNA which has been previously treated with $100 \boldsymbol{\mu M}$ cisplatin. Endonuclease IV selectively cleaves DNA 5' to apurinic sites. DNA ladder (Lane \#1); circular pUC19 DNA control (Lane \#2); linearized pUC19 DNA standard (Lane \# 3); linearized pUC19 DNA $100 \mu \mathrm{M}$ cisplatin, pH 5.0, 3 $\mathrm{h}$ (Lane \#4), $100 \mu \mathrm{M}$ cisplatin-treated linearized pUC10 DNA reacted with buffer only for $4 \mathrm{~h}$ (Lane \#5), $8 \mathrm{~h}$ (Lane \#6), $12 \mathrm{~h}$ (Lane \#7), $30 \mathrm{~h}$ (Lane \#8), and $42 \mathrm{~h}$ (Lane \#9); linearized pUC19 DNA reacted with Endonuclease IV for $4 \mathrm{~h}$ (Lane \#10), $8 \mathrm{~h}$ (Lane \#11), $12 \mathrm{~h}$ (Lane \#12), $30 \mathrm{~h}$ (Lane \#13), and $42 \mathrm{~h}$ (Lane \#14). Conditions (Lanes \#4-\#14): linearized pUC19 DNA (15.4 $\mu \mathrm{M}$ base pair) that has been reacted with $100 \mu \mathrm{M}$ cisplatin in $10 \mathrm{mM}$ sodium citrate buffer, $\mathrm{pH} 5.0$ for 4 hour at $37^{\circ} \mathrm{C}$ (Lane \#4); the DNA (3.9 $\mu \mathrm{M}$ base pair) was further reacted with NEBuffer 3.1® (New England Biolabs ${ }^{\circledR}$ ), pH 7.9, at $37^{\circ} \mathrm{C}$ for $4 \mathrm{~h}, 8 \mathrm{~h}, 12 \mathrm{~h}, 30 \mathrm{~h}$, or $42 \mathrm{~h}$ (Lanes \#5-\#9); the DNA (3.9 $\mu \mathrm{M}$ base pair) was further reacted with 20 units of Endonuclease IV in NEBuffer $3.1 \circledR$ (New England Biolabs ${ }^{\circledR}$ ), $\mathrm{pH}$ 7.9, at $37^{\circ} \mathrm{C}$ for 4 h, 8 h, 12 h, 30 h, or 42 h (Lanes \#10-\#14). The DNA was not re-purified and was directly analyzed by native agarose gel electrophoresis $(90 \mathrm{~V}, 2$ h). $\mathrm{SC}=$ supercoiled, linear $=$ linearized DNA cross-linked by cisplatin. 

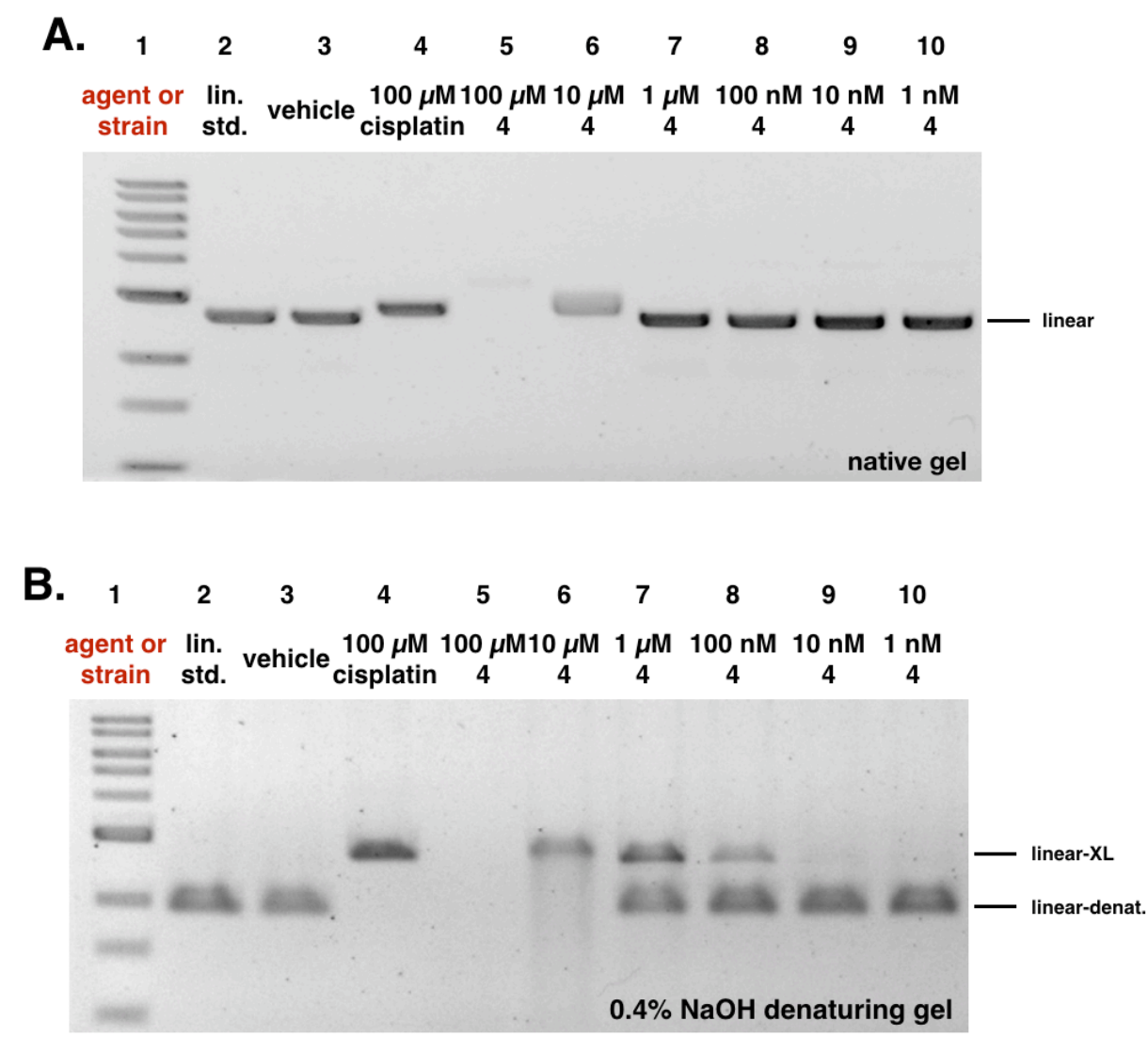

Fig. S15. DNA cross-linking assay employing linear pUC19 DNA and synthetic colibactin linear precursor 4. A. Native gel. B. $0.4 \% \mathrm{NaOH}$ denaturing gel. 5\% DMSO was used as vehicle (negative control), and $100 \mu \mathrm{M}$ cisplatin was used as positive control. DNA ladder (Lane \#1); linearized pUC19 DNA standard (Lane \#2); 5\% DMSO (Lane \#3); $100 \mu \mathrm{M}$ cisplatin (Lane \#4); $100 \mu \mathrm{M} 4$ (Lane \#5); $10 \mu \mathrm{M} 4$ (Lane \#6); $1 \mu \mathrm{M} 4$ (Lane \#7); $100 \mathrm{nM} 4$ (Lane \#8); $10 \mathrm{nM} 4$ (Lane \#9); $1 \mathrm{nM} 4$ (Lane \#10). Conditions (Lane \#3): linearized pUC19 DNA (15.4 $\mu \mathrm{M}$ in base

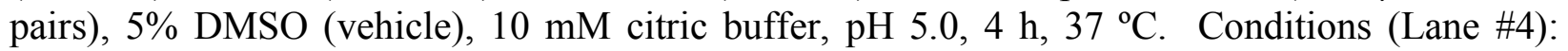
linearized pUC19 DNA (15.4 $\mu \mathrm{M}$ in base pairs), 5\% DMSO (vehicle), $100 \mu \mathrm{M}$ cisplatin, $10 \mathrm{mM}$ citric buffer, $\mathrm{pH} 5.0,4 \mathrm{~h}, 37^{\circ} \mathrm{C}$. Conditions (Lanes \#5-\#10): circular pUC19 DNA (15.4 $\mu \mathrm{M}$ in base pairs), $4(100 \mu \mathrm{M}-1 \mathrm{nM}), 5 \%$ DMSO, $10 \mathrm{mM}$ citric buffer, $\mathrm{pH} 5.0,4 \mathrm{~h}, 37^{\circ} \mathrm{C}$. The DNA was analyzed either (Fig. S15A) by native agarose gel electrophoresis, or (Fig. S15B) by $0.4 \%$ $\mathrm{NaOH}$ denaturing agarose gel electrophoresis $(90 \mathrm{~V}, 1.5 \mathrm{~h})$. Linear = linearized DNA, Lineardenat. $=\mathrm{DSB} /$ linearized DNA in denaturing form, linear-XL $=\mathrm{DSB} /$ linearized DNA cross-linked by colibactin or cisplatin. 

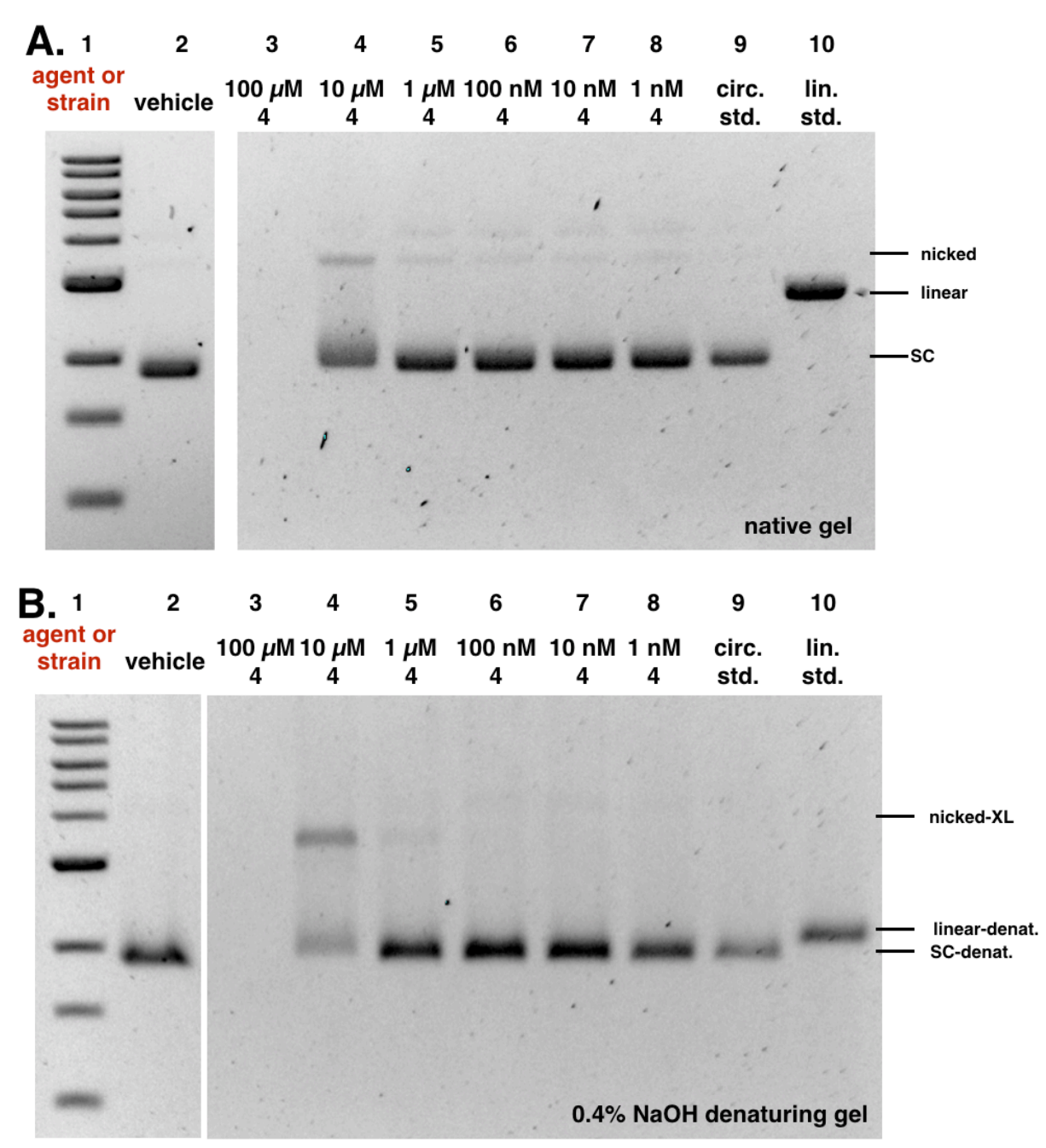

Fig. S16. DNA plasmid cleavage assay employing circular pUC19 DNA and synthetic colibactin linear precursor 4. A. Native gel; B. 0.4\% NaOH denaturing gel. 5\% DMSO was used as vehicle. DNA ladder (Lane \#1); 5\% DMSO (Lane \#2); $100 \mu \mathrm{M} 4$ (Lane \#3); $10 \mu \mathrm{M} 4$ (Lane \#4); 1 MM 4 (Lane \#5); $100 \mathrm{nM} 4$ (Lane \#6); $10 \mathrm{nM} 4$ (Lane \#7); $1 \mathrm{nM} 4$ (Lane \#8); circular pUC19 plasmid standard (Lane \#9); linearized pUC19 plasmid standard (Lane \#10). Conditions (Lane \#2): circular pUC19 DNA (15.4 $\mu \mathrm{M}$ in base pairs), 5\% DMSO (vehicle), $10 \mathrm{mM}$ citric buffer, $\mathrm{pH} 5.0,4 \mathrm{~h}, 37^{\circ} \mathrm{C}$. Conditions (Lanes \#3-\#8): circular pUC19 DNA (15.4 $\mu \mathrm{M}$ in base pairs), $4(100 \mu \mathrm{M}-1 \mathrm{nM}), 5 \%$ DMSO, $10 \mathrm{mM}$ citric buffer, $\mathrm{pH} 5.0,3 \mathrm{~h}, 37^{\circ} \mathrm{C}$. The DNA was analyzed either (Fig. S16A) by native agarose gel electrophoresis, or (Fig. S16B) by $0.4 \% \mathrm{NaOH}$ denaturing agarose gel electrophoresis $(90 \mathrm{~V}, 1.5 \mathrm{~h}) . \mathrm{SC}=$ supercoiled, nicked $=\mathrm{SSB}$, linear $=$ $\mathrm{DSB}$, Linear-denat. $=\mathrm{DSB} /$ linearized DNA in denaturing form, linear-XL $=\mathrm{DSB} /$ linearized DNA cross-linked by colibactin or cisplatin. 


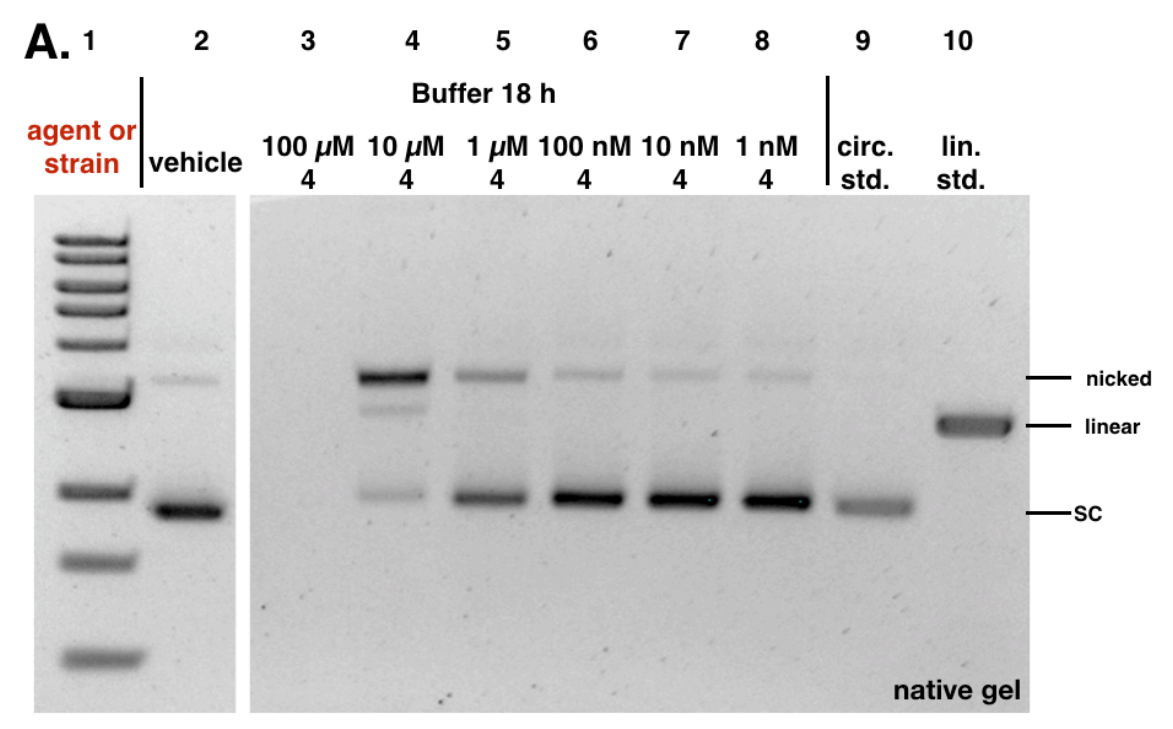

Fig. S17A. Plasmid DNA buffer stability test employing circular pUC19 DNA that had been previously treated with synthetic colibactin linear precursor 4 at different concentrations. $5 \%$ DMSO was used as vehicle when preparing the DNA samples for testing. DNA ladder (Lane \#1); post buffer-reacted after 5\% DMSO (Lane \#2); post buffer-reacted after $100 \mu \mathrm{M} 4$ (Lane \#3); post buffer-reacted after $10 \mu \mathrm{M} 4$ (Lane \#4); post buffer-reacted after $1 \mu \mathrm{M} 4$ (Lane \#5); post buffer-reacted after $100 \mathrm{nM} 4$ (Lane \#6); post buffer-reacted after $10 \mathrm{nM} 4$ (Lane \#7); post bufferreacted after $1 \mathrm{nM} 4$ (Lane \#8); circular pUC19 plasmid standard (Lane \#9); linearized pUC19 plasmid standard (Lane \#10). Conditions (Lane \#2): the 5\% DMSO-treated circular pUC19 DNA (3.9 $\mathrm{\mu M}$ in base pairs), NEBuffer $3.1{ }^{\circledR}$ (New England Biolabs ${ }^{\circledR}$ ), $\mathrm{pH} 7.9$, at $37^{\circ} \mathrm{C}$ for $18 \mathrm{~h}$. Conditions (Lanes \#3-\#8): 4 (100 $\mu \mathrm{M}-1 \mathrm{nM})$-treated circular pUC19 DNA (3.9 $\mu \mathrm{M}$ in base pairs), NEBuffer 3.1 ${ }^{\circledR}$ (New England Biolabs ${ }^{\circledR}$ ), $\mathrm{pH} 7.9$, at $37^{\circ} \mathrm{C}$ for $18 \mathrm{~h}$. The DNA was not further purified and was directly analyzed by native agarose gel electrophoresis $(90 \mathrm{~V}, 2 \mathrm{~h})$. $\mathrm{SC}=$ supercoiled, nicked $=\mathrm{SSB}$, linear $=$ DSB . 


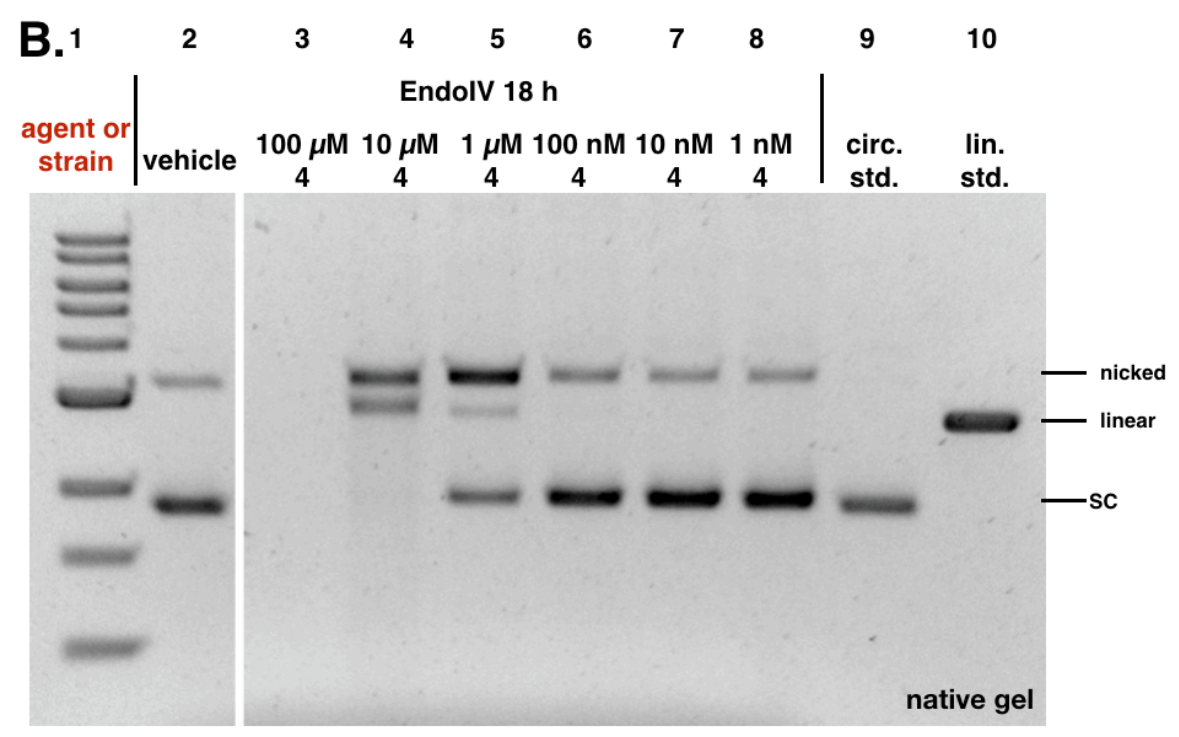

Fig. S17B. Plasmid DNA Endonuclease IV stability test employing circular pUC19 DNA that had been previously treated with synthetic colibactin linear precursor 4 at different concentrations. Endonuclease IV selectively cleaves DNA $5^{\prime}$ to apurinic sites. 5\% DMSO was used as vehicle when preparing the DNA samples for testing. DNA ladder (Lane \#1); post EndoIV-reacted after 5\% DMSO (Lane \#2); post EndoIV-reacted after $100 \mu \mathrm{M} 4$ (Lane \#3); post EndoIV-reacted after $10 \mu \mathrm{M} 4$ (Lane \#4); post EndoIV-reacted after $1 \mu \mathrm{M} 4$ (Lane \#5); post EndoIV-reacted after $100 \mathrm{nM} 4$ (Lane \#6); post EndoIV-reacted after $10 \mathrm{nM} 4$ (Lane \#7); post EndoIV-reacted after $1 \mathrm{nM} 4$ (Lane \#8); circular pUC19 plasmid standard (Lane \#9); linearized pUC19 plasmid standard (Lane \#10). Conditions (Lane \#2): the 5\% DMSO-treated circular pUC19 DNA (3.9 $\mu \mathrm{M}$ in base pairs), 20 units of Endonuclease IV (New England Biolabs ${ }^{\circledR}$ ), NEBuffer 3.1 ${ }^{\circledR}$ (New England Biolabs ${ }^{\circledR}$ ), $\mathrm{pH} 7.9$, at $37^{\circ} \mathrm{C}$ for $18 \mathrm{~h}$. Conditions (Lanes \#3-\#8): $4(100 \mu \mathrm{M}-1 \mathrm{nM})$-treated circular pUC19 DNA (3.9 $\mu \mathrm{M}$ in base pairs), 20 units of Endonuclease IV (New England Biolabs ${ }^{\circledR}$ ), NEBuffer 3.1 ${ }^{\circledR}$ (New England Biolabs $\left.{ }^{\circledR}\right)$, pH 7.9, at $37^{\circ} \mathrm{C}$ for $18 \mathrm{~h}$. The DNA was not further purified and was directly analyzed by native agarose gel electrophoresis $(90 \mathrm{~V}, 2 \mathrm{~h}) . \mathrm{SC}=$ supercoiled, nicked $=\mathrm{SSB}$, linear $=\mathrm{DSB}$. 